\title{
BETTER MEDICINES FOR CHILDREN: CHALLENGES AND UNMET NEEDS
}

\author{
${ }^{I}$ Slažneva, J. $-{ }^{2}$ Kákošová, $V .-{ }^{1}$ Kuželová, $M$. \\ ${ }^{1}$ Comenius University in Bratislava, Faculty of Pharmacy, Department of Pharmacology \\ and Toxicology, \\ ${ }^{2}$ Hospital pharmacy, University Children's hospital, Bratislava
}

\begin{abstract}
This review deals with the use of medicinal products in children. Many medicinal products administered routinely to paediatric patients have been either not licensed for use in children (unlicensed use) or have been prescribed outside the terms of their product license (off-label prescribing). A lot of surveys have been conducted in the context of identifying the extent of offlabel used drugs in children documenting high rates (45-60\%) of such use. Recognising and meeting challenges as development of suitable formulations for very young children and realization of clinical trials involving children present important steps in the enhancement of the present situation. To improve the health of children in Europe, the Regulation (EC) No 1901/2006 addressing the pharmaceutical industry, research teams and member states proposing important incentives and obligations was assigned. Paediatric Investigation Plan and Paediatric Use Marketing Authorisation present the key measures of the EU regulation on medicinal products for paediatric patients.
\end{abstract}

Keywords: Children - Off-label drug use - Paediatric Regulation

\section{INTRODUCTION}

Medicinal products have to pass extensive studies, both preclinical and clinical, before being placed on the market to ensure safety, efficacy and high quality [1]. Recent years have shown growing concerns about the widespread prescribing of marketed drugs either not labelled or inadequately labelled for use in paediatric population. Children, a particularly vulnerable patient population, are routinely given medicinal products that lack specific paediatric information and have not been studied or authorised for such use. Risks of the present situation include potential adverse reactions from overdosing, under-dosing leading to loss of efficacy and the use of unsuitable formulation [2]. There are several likely reasons for this lack of evidence- 
based paediatric pharmacotherapy. The industrial costs associated with paediatric product development result usually in poor return. Furthermore, there are special ethical and practical issues in involvement of children in research [3]. While science and research in clinical pharmacology have made significant progress over last decades, little has been accomplished in the unsatisfying availability of children's medicines. Of all authorised medicines approved by the European Medicines Agency (EMA) over the 10-year period (1995-2005), only one third was licensed for use in paediatric patients. In the United States in the period 1973-1997 the proportion of approved medicines not labelled for children remained stable at $71-81 \%$ [4]. The use of a medicinal product outside the terms of marketing authorisation or Summary of Product Characteristics is defined in current publications as off-label use. There are several categories of off-label classification presented in table 1 [4].

\section{Table 1. Off-label classification according to main reasons}

- No directions for use in children or mention of children in the SPC

- Not recommended or contraindicated for use in children

- Outside approved age range

- Prescribed for not approved indications

- Formulation not suitable for use in particular paediatric group (pills $<2$ years)

- Outside dosage recommendations

- Administration by an alternative route

The exact definition of off-label use of medicinal products and explanation of other important terms related to the topic are stated in table $2[1,6]$.

Table 2. Glossary

- OFF-LABEL USE OF A MEDICINE - any use or administration of a medicinal product outside the terms of Summary of Product Characteristics with regard to approved indication, age-group, dose and frequency, route of administration, suitable formulation.

- PAEDIATRIC INVESTIGATION PLAN - PIP - refers to a research and development programme aimed at ensuring that the necessary data are generated determining the conditions in which a medicinal product may be authorised to treat the paediatric population.

- PAEDIATRIC USE MARKETING AUTHORISATION - PUMA - means a marketing authorisation granted in respect of a medicinal product, which is protected by a supplementary protection certificate or by a patent covering exclusively therapeutic indications which are relevant for use in paediatric population.

- PAEDIATRIC COMMITTEE - scientific committee within the European Medicines Agency with expertise and competence in the development of medicinal products to treat paediatric population.

- SUMMARY OF PRODUCT CHARACTERISTICS - SPC - is the basis of information for health professionals on how to use the medicinal product safely and effectively. 


\section{Recognizing the challenges of developing paediatric medicines}

\section{- Physiological and pharmacological challenges}

Children are not just small adults, either from a biological or pharmacological development perspective. Infancy and childhood is a period of rapid growth and maturation. The younger the child the more significant the differences are in comparison to an adult [7]. Furthermore, it is often overlooked that the paediatric population is not a homogenous sub-group and that the proper use of drugs in children requires an understanding of the alternations in pharmacokinetics and pharmacodynamics which occur, particularly in neonates ( age up to 1 month) and infants (age up to 4 years) [8].

\section{- Formulation challenges}

The development of formulations suitable for very young children can be challenging to pharmaceutical scientists and very few drugs have been developed specifically with children in mind. There is limited knowledge available on the acceptability of different dosage forms, administration volumes, dosage form size and the safety of excipients in relation to the age and development status of the particular child. In consequence, healthcare professionals are frequently forced to manipulate adult dosage forms to make them suitable for dosing to a paediatric patient [7]. Usually there is little information on the bioavailability of manipulated dosage forms such as crushed or halved tablets, cut or covered transdermal patches and opened capsules. Furthermore, it has to be kept in mind that a child may not be able to metabolise or eliminate all excipients in the drug in the same way as an adult. Although today new excipients are required to undergo extensive safety testing and well established safety data were collected on existing excipients, maximum tolerated doses are usually referenced for use in adults. Direct application of this data in children remains doubtful. Examples of potential risks associated with frequently used pharmaceutical excipients are shown in table 3 [9].

Table 3. Examples of potential risks conducted with pharmaceutical excipients

\begin{tabular}{llll} 
Excipient & Function & Potential risk & Approved age \\
\hline \hline Aspartame & sweetener & hyperactivity & - \\
Benzyl alcohol & antimicrobial preservative & neurotoxicity/fatalities & $>6$ months \\
Propyl gallate & antioxidant & methaemoglobineamia & - \\
Propylene glycol & solvent/preservative & CNS adverse events & $>4$ years
\end{tabular}

\section{- Ethical challenges}

Clinical trials involving children are among others definitely the most challenging types of studies. Ethical and moral implications of subjecting children to research have been extensively discussed. As children have generally been viewed as incompetent and 
vulnerable, they have often been excluded from research [10]. There is no doubt that the lack of clinical trials presents the main reason for this serious lack of evidence-based pharmacotherapy. At the same time there is a growing opinion that every child has the right to be treated with properly researched, effective and safe medicines [4].

\section{How does the EU`s paediatric medicines legislation serve children`s needs?}

Market forces alone have proved to be insufficient to stimulate an adequate research in the development and authorisation of medicinal products available for paediatric population. Almost 10 years after the US regulations on paediatric drugs were resolved, similar regulations were introduced in the EU legislation [11]. The Regulation (EC) No 1901/2006 of the European Parliament and of the Council, which entered into force on 26 January 2006, proposes a combination of incentives and obligations aimed to facilitate the development and accessibility of medicinal products for use in children from birth to less than 18 years and thus improve the health of children in Europe. The main objectives should be accomplished without subjecting children to unnecessary trials or delaying the authorisation of medicinal products for other population subgroups [1]. Improving the availability of information and evidence on the use of medicines in children was meant to be one of the main goals of the regulation. A crucial element in the presented legislation was the creation of a multidisciplinary scientific committee on paediatric medicines - Paediatric Committee (PDCO) at the EMA. PDCO cooperates with other EMA committees on any matters related to the development of medicinal products for use in children. It is primarily responsible for the assessment and agreement of paediatric investigation plans - PIP. As an incentive to sponsors developing medicinal products for paediatric patients the committee provides free scientific advice. In order to increase the availability of information on the use of medicines for children and to avoid unnecessary repetition of studies in paediatric population, results of paediatric clinical trials inside and outside the EU should be published in the EU clinical trial database - EudraCT. Moreover, to support the research in children, EMA launched a European network of existing national and European paediatric centres [3].

\section{Main legislative proposals and implements}

The EU regulation on medicinal products for paediatrics may change the present unsatisfactory situation by facilitating the development and ensuring that drugs which are used to treat the paediatric population are subjected to ethical research of high quality [3]. Therefore, the following implements introduced by the EU legislation as key measures are going to be characterised: Paediatric Investigation Plan requested at an early stage of clinical development for all new chemical entities and Paediatric Use Marketing Authorisation for drugs with expired patent protection[11].

- Paediatric Investigation Plan - a drug-development plan that has to be agreed by Paediatric Committee in advance and it is binding for companies as it became an 
integral part of the introduction of all medicines in the EU. The plan should contain detailed information on all planned clinical investigations and development strategy for age-appropriate formulations [2]. Once the plan is complete the compliance with the agreed studies are checked. The compliance check is necessary before an application for marketing authorisation or extension to add a new indication, pharmaceutical form or route of administration can be considered as valid. If all the measures included in the agreed paediatric investigation plan are complied with, relevant information on the results of studies stated in the product information and if the product is authorised in all member states of EU a six-month extension of the Supplementary Protection Certificate will be granted. The patent for orphan drugs will be extended from 10 to 12 years [1].

- Paediatric Use Marketing Authorisation - a new type of drug licensing, the goal of which is to stimulate the development of medicinal products without patent protection. Off-patent drugs developed specifically for paediatric use can benefit from a paediatric-use authorisation with 10 years data exclusivity [11].

\section{Current situation among European countries}

One of the provisions of the Regulation (EC) No 1901/2006 on paediatric medicines calls for collecting available data on all existing uses of medicinal products in EU member states. These data shall provide detailed information on crucial paediatric needs and enable to update the existing priority list of off-patent medicinal products. The priority list is considered to be an important tool for directing the research of paediatric drugs within the EU. Many surveys had been conducted in this context throughout countries of European Union since. Majority of the submitted data focused on hospitalised children and off-label drug use within various age sub-groups. Some of them were performed at specialised wards as paediatric gastroenterology or neonatal intensive care unit $[12,13]$. Most of the results confirm widespread off-label and unlicensed use of drugs in Europe, which refers to $45-60 \%$ of all administered medicinal products to paediatric population. Higher rates, up to $90 \%$, were reported in the premature, term neonates and in infants. The most frequent medicines used off-label and unauthorised belong to the following therapeutic classes: antiarrhythmics, antihypertensives (renin-angiotensin inhibitors, beta-blockers), proton pump inhibitors, $\mathrm{H}_{2}$-receptor antagonists, antiasthmatics and antidepressants (mainly selective serotonin reuptake inhibitors, serotonin-norepinephrine reuptake inhibitors and tricyclic antidepressants). Both oral and parenteral formulations are being used unauthorised or off-label, pointing out to the lack of appropriate dosages and strengths for treated agegroups. Observed differences with regard to the licensing status of medicinal products across the EU could be partially explained by different prescribing habits, regulatory status in particular country as well by using various information sources or different data collection methods [14]. Despite the request of EMA to collect relevant data on use of drugs in children in all EU member states, the Slovak republic and some other 
countries have not provided any information on the extent and nature of off-label used medicinal products in paediatrics yet.

\section{CONCLUSION}

Paediatric regulation is supposed to improve the unacceptable situation by ensuring that new medicines are meeting paediatric needs with implementation of PIPs agreed by the Paediatric Committee. Furthermore, the regulation includes funding of studies into off-patent medicinal products with submission of a PUMA. These initiatives aim to promote greater awareness and research in the paediatric population. Results of majority national studies demonstrated that there are still high rates of off-label used drugs in children, underlining the need to stimulate scientific data collection by means of clinical studies performed in paediatric population.

\section{REFERENCES}

1. Regulation (EC) No 1901/2006 of the European Parliament and of the Council; on medicinal products for paediatric use and amending Regulation (EEC) No 1768/92, Directive 2001/20/EC, Directive 2001/83/EC and Regulation (EC) No 726/2004- of 12 December 2006. Available at: http://eur-lex.europa.eu/LexUriServ/site/en/consleg/2006/R/02006R190120070126-en.pdf (accessed on 25.08.2011).

2. BUSH, A.: Evidence-based medicines for children: important implications for new therapies at all ages. EurRespir J 28, 2006, p. 1069-1072.

3. PERMANAND, G. - MOSSIALOS, E. - MCKEE, M.: The EU's new paediatric medicines legislation: serving children`s needs? Arch Dis Child 92, 2007, p. 808-811.

4. HOPPU, K.: Paediatric clinical pharmacology - at the beginning of a new era. Eur $J$ ClinPharmacol64, 2008, p. 201-205.

5. LINDELL-OSUAGWU, L. - KORHONEN, M.J. - SAANO, S. - HELIN-TANNINEN, M. NAARANLAHTI, T. - KOKKI, H.: Off-label and unlicensed drug prescribing in three paediatric wards in Finland and review of the international literature. J Clin Pharm Ther 34, 2009, p. 277-287.

6. A guideline on summary of product characteristics. Available at:http://ec.europa.eu/health/files/eudralex/vol-2/c/smpc_guideline_rev2_en.pdf (accessed on 10.09.2011).

7. ERNEST, T. B. - ELDER, D. P. - MARTINI, L. G. - ROBERTS, M. - FORD, J. L.: Developing paediatric medicines: identifying the needs and recognizing the challenges. J Clin Pharm Ther 59, 2007, p. 1043-1055.

8. COnstable, S. - Winstanley, P. - WAlley, T.: Medical Pharmacology. Third edition, Churchill Livingstone Elsevier 2007, p. 278-279.

9. EMA. Reflection paper: formulation of choice for the paediatric population. 2006. EMEA/CHMP/PEG/194810/2005.

10. FORTWENGEL, G. - OSTERMANN, H. - STAUDINGER, R.: Better medicines for children: Clinical Investigation of Medicinal Products in the Paediatric Population - A QA Perspective. Published online in Wiley InterScience. DOI: 10.1002/qaj.422.

11. BREITKREUTZ, J.: European Perspectives on Paediatric Formulations. ClinTher 30, 2008, p. 2146-2154. 
12. DELl'AERA, M. - GASBARRO, A. R. - PADOVANO, M. - LAFORGIA, N. CAPODIFERRO, D. - SOLARINO, B. - QUARANTA, R. - DELL'ERBA, S. A.: Unlicensed and off-label use of medicines at a neonatology clinic in Italy. Pharm World Sci 29, 2007, p. 361-367.

13. DICK, A. - KEADY, S. - MOHAMED, F. - BRAYLEY, S. - THOMSON, M. - LLOYD, B.W. - HEUSCHKEL, R. - AFZAL, N. A.: Use of unlicensed and off-label medications in paediatric gastroenterology with a review of the commonly used formularies in the UK. Aliment PharmacolTher 17, 2003, p. 571-575.

14. Report on the survey of all paediatric uses of medicinal products in Europe. Available at: http://www.ema.europa.eu/docs/en_GB/document_library/Report/2011/01/WC500101006.pdf (accessed on 10.09.2011).

Registered:October, 2011

Accepted:January, 2012

\author{
PharmDr. Jana Slažneva \\ FacultyofPharmacy \\ ComeniusUniversity \\ Odbojárov 10 \\ 83232 Bratislava \\ slazneva@fpharm.uniba.sk
}

\title{
VÝZVY PRI VÝVOJI LIEKOV PRE DETI
}

\author{
${ }^{1}$ Slažneva, J. $-{ }^{2}$ Kákošová, $V .-{ }^{1}$ Kuželová, $M$. \\ ${ }^{1}$ Univerzita Komenského v Bratislave, Farmaceutická fakulta, \\ Katedra farmakológie a toxikológie, \\ ${ }^{2}$ Nemocničná lekáreň, DetskáFakultnáNemocnica s Poliklinikou, Bratislava
}

Práca sa zaoberá používaním liekov u detí. Mnohé bežne podávané lieky neboli pre pediatrických pacientov registrované alebo sú používané mimo podmienok uvedených v SPC off-label použitie liekov. Viaceré dosial' uskutočnené štúdie potvrdili vysoký podiel (45-60 \%) off-label použitých liekov u detí. Dôležitý krok k zlepšeniu dnešnej situácie predstavuje vývoj vhodných liekových foriem pre najmenšie deti a realizácia klinických štúdií aj na detskej populácii. Prijaté Nariadenie Európskeho parlamentu a Rady č. 1901/2006 o liekoch pre pediatrické použitie adresované výrobcom liekov, výskumným tímom a členským štátom EÚ obsahuje významné povinnosti a stimuly na docielenie zlepšenia zdravia detí v Európe. Pediatrický výskumný plán a povolenie na uvedenie na trh na pediatrické použitie predstavujú kl'účové opatrenia európskej legislatívy o liekoch pre pediatrických pacientov.

Acta Fac. Pharm. Univ. Comen., Suppl. 2012, VI, p. $21-27$. 